\section{Evaluating the Efficacy of Dazomet for the Control of Annual Bluegrass Seed Germination in Renovated Turf Surfaces}

\author{
Jacob S. Bravo ${ }^{1,3}$, Thomas Okada Green ${ }^{1}$, James R. Crum ${ }^{1}$, \\ John N. Rogers III ${ }^{1}$, Sasha Kravchenko ${ }^{1}$, and Charles A. Silcox ${ }^{2}$
}

AdDitional INDEX wORDs. soil sterilant, Poa annua, renovation

Summary. The soil sterilant, dazomet, is the primary product in the turfgrass industry set to take the position of methyl bromide, which is no longer available for use on turfgrass. With turf surface renovations taking place throughout the country, the need for an effective soil sterilant is critical. This study focused on the ability of dazomet to inhibit germination of annual bluegrass (Poa annua) seeds when it is used as per the current, turf focused, label which decreased legal application rates across all surfaces. This study was a four-way factorial in a splitsplit plot design with whole plots in a randomized complete block design arrangement with three replications. The first factor, soil type, included two levels. Soil-type plots $(60 \times 95 \mathrm{ft})$ were either sand capped from topdressing over the native Capac loam or they were the native Capac loam. Sand topdressing was applied biweekly at a rate of $0.14 \mathrm{yard}^{3} / 1000 \mathrm{ft}^{2}$, April to September since 2011; accumulating a total of 1.5 inches of sand. Each of three replicated blocks consisted of two soil-type plots. The second factor was time trials, with two levels of starting times, June and August. Each soil-type plot was split into two subplots and the trials were assigned at random to subplots within each plot. The third factor, soil preparation, involved either removing the upper 1.5 inches of the sod/soil layer or spraying plots with glyphosate and then heavily cultivating them. This cultivation included a vertical-cut and a core cultivation with an aerator using 0.5 -inch hollow tines at $2 \times 2$-inch spacing. The fourth factor, treatment regime, comprised 11 parameters that encompassed dazomet application rate, incorporation method, and the technique used to seal the soil surface. Dazomet treatments were applied with a shaker bottle, at rates that included $262,421,525$, and $262 \mathrm{lb} /$ acre applied twice at a 5-day interval. The treatments were incorporated into the soil either through 1 inch of irrigation, through four consecutive days of irrigation following this schedule: $1,0.5,0.25,0.125$ inch each day after application, respectively, or physically $(P)$ with a rotary tiller set to 1.5 inches, the depth of the topdressing layer. All $P$ incorporated plots were hand rolled following application, regardless of the tarping procedure. Water-incorporated plots were either sealed with a clear plastic 4-mil tarp or they were left unsealed. Researchers evaluated the level of germination control by counting individual annual bluegrass seedlings using a $1 \times 1$ - $\mathrm{ft}$ grid. A significant interaction occurred between soil type and soil preparation as well as between soil type and treatment. A three-way interaction also occurred between trial, treatment and soil preparation. In general, tarped treatments showed better annual bluegrass control compared with nontarped treatments. Furthermore, sand topdressed soils showed lower numbers of annual bluegrass as compared with native soils. Finally, reduced annual bluegrass germination was found in plots that had the top 1.5 inches of material removed.

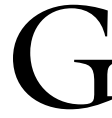

olf course renovation is tremendously popular as an alternative to new course construction

We thank the Michigan Turfgrass Foundation for their continued support of turfgrass research. We are also grateful for the maintenance staff and personnel at the Michigan State University Hancock Turfgrass Research Center. Finally, thank you to Eric Chestnut for his efforts throughout the entirety of this project.

${ }^{1}$ Department of Plant, Soil and Microbial Sciences, Michigan State University, East Lansing, MI 48824

${ }^{2}$ Amvac Chemical Corp, Product Development, 220 Paper Mill Circle, Lincoln University, PA 19352

${ }^{3}$ Corresponding author. E-mail: bravojac@msu.edu.

https://doi.org/10.21273/HORTTECH03930-17 throughout the nation (Park and Landschoot, 2003). To begin that renovation, most courses seek a method to eliminate existing plants and seeds to start anew without compromising the architectural integrity of the green or fairway (Calhoun and Branham, 1995). Dazomet is the soil sterilant options available due to the removal of methyl bromide from the market (Ristaino and Thomas, 1997). Dazomet is sold in a fine granular formulation and once applied and incorporated, turns into methyl isothiocyanate gas, killing all existing tissues as well as the seed within the soil (McClellan, 2009). Early studies have shown that when combined with either tilling or a plastic cover, dazomet can be an effective sterilant (Askew et al., 2004). However, tillage is often not a practical option when renovating turf areas, so a less intrusive method of incorporation is necessary (Hardebeck et al., 2001). All previous research with dazomet was conducted based on the product's initial label, which was focused more on production agriculture fields. The goal of current research is to optimize weed seed germination control when dazomet is used as per the current, turf-focused label, which decreases legal application rates across all surfaces, regardless of incorporation method.

Dazomet has the capability to suppress emergence for a multitude of weed species. Park and Landschoot (2003) and previous research has proven that a multitude of rates of dazomet are effective in controlling annual bluegrass emergence (Branham et al., 2004). It is also known that the addition of a plastic cover will increase efficacy of dazomet (Park and Landschoot, 2001). Dazomet has also been formerly studied in combination with other chemistries; however, this was not an attempt to control annual bluegrass (Unruh et al., 2002). In addition, efficacy of dazomet has been tested by adding it to rootzone mix before initial

\begin{tabular}{llll}
\hline $\begin{array}{l}\text { Units } \\
\text { To convert U.S. to SI, } \\
\text { multiply by }\end{array}$ & U.S. unit & SI unit & $\begin{array}{l}\text { To convert SI to U.S., } \\
\text { multiply by }\end{array}$ \\
\hline 0.3048 & $\mathrm{ft}$ & $\mathrm{m}$ & 3.2808 \\
0.0929 & $\mathrm{ft}$ & $\mathrm{m}^{2}$ & 10.7639 \\
9.3540 & gal $/ \mathrm{acre}$ & $\mathrm{L} \cdot \mathrm{ha}^{-1}$ & 0.1069 \\
2.54 & inch $(\mathrm{es})$ & $\mathrm{cm}$ & 0.3937 \\
1.1209 & lb/acre & $\mathrm{kg} \cdot \mathrm{ha}^{-1}$ & 0.8922 \\
0.0254 & mil & $\mathrm{mm}$ & 39.3701 \\
1.7300 & $\mathrm{oz} / \mathrm{inch}^{3}$ & $\mathrm{~g} \cdot \mathrm{cm}^{-3}$ & 0.5780 \\
82.2960 & yard $/ 1000 \mathrm{ft}^{2}$ & $\mathrm{~m}^{3} \cdot \mathrm{ha}^{-1}$ & 0.0122 \\
$\left({ }^{\circ} \mathrm{F}-32\right) \div 1.8$ & ${ }^{\circ} \mathrm{F}$ & ${ }^{\circ} \mathrm{C}$ & $\left({ }^{\circ} \mathrm{C} \times 1.8\right)+32$
\end{tabular}


seeding and suppressed germination was seen in multiple weed species (Brecke et al., 2005).

Sand topdressing is a widely used cultural practice as research has shown its ability to increase playing surface firmness while also reducing the disease (Skorulski et al., 2010). Golf courses around the country now have soil profiles consisting of various amounts of sand layers, and therefore, comparing the effects on efficacy of dazomet in these varying soil types is warranted. About $80 \%$ of viable annual bluegrass seed can be found in the top 2 inches of the soil profile (Branham et al., 2004). Sod removal of this layer as the first step during a renovation can be labor intensive, and if dazomet is effective without sod removal, then labor costs could be reduced. The objective of this research was to investigate efficacy of dazomet rates under combinations of the soil type and preparation method for annual bluegrass seed germination.

\section{Materials and methods}

The experiment was conducted at the Michigan State University Hancock Turfgrass Research Center, located in East Lansing, MI. The site is about a 15-year-old, experimental mixed-stand, $60 \%$ creeping bentgrass (Agrostis stolonifera) and 40\% annual bluegrass, and simulated golf fairway mowed at 0.5 inch.

This study was a four-way factorial in a split-split plot design with whole plots in a randomized complete block design arrangement with three replications. The first factor, soil type, included two levels. Soil-type plots $(60 \times 95 \mathrm{ft})$ were either sand capped from topdressing over the native soil or they were the native soil. The native soil of this site is a Capac loam (fine-loamy, mixed, mesic Aquic Glossudalfs) with a bulk density of $1.5 \mathrm{~g} \cdot \mathrm{cm}^{-3}$, a pH of 6.6 and $2.5 \%$ (by weight) organic matter on average. Sand top-dressing was applied biweekly at a rate of 0.14 yard $^{3} / 1000 \mathrm{ft}^{2}$ from April to September since 2011; accumulating a total of 1.5 inches of sand. Each of three replicated blocks consisted of two soil-type plots.

The second factor is time of trials, with two levels of starting times, June and Aug. 2015. Each soil-type plot was split into two subplots, and the trials were assigned at random to subplots within each plot.

The third factor is soil preparation, involved either removing the upper 1.5 inches sod/soil layer or applying glyphosate followed by aggressive cultivation. The glyphosate was applied once as a $5 \%$ solution using a carbon dioxide-supplied backpack sprayer, calibrated to apply $45 \mathrm{gal} /$ acre. The cultivation included a vertical-cut set at $\approx 0.125$ inch and core cultivation with an aerator (ProCore 648; Toro, Bloomington, $\mathrm{MN}$ ) using 0.5 -inch hollow tines at $2 \times 2$ inch spacing.

The fourth factor, treatment regime, was comprised of 11 parameters that encompassed dazomet application rate, incorporation method, and the technique used to seal the soil surface (Table 1). Dazomet treatments were applied with a shaker bottle, at rates that included 262, 421, 525 , and $262 \mathrm{lb} /$ acre applied twice at a 5-d interval. The treatments were incorporated into the soil either through 1 inch of irrigation (single watering), through four consecutive days (multiple waterings) of irrigation after this schedule: $1,0.5,0.25,0.125$ inch each day after application, respectively, or $\mathrm{P}$ with an L-tine rotary tiller (FR500; Honda, Alpharetta, GA) set to 1.5 inches, about the depth of the topdressing layer. All P incorporated plots were hand rolled following application, regardless of the tarping procedure. Water-incorporated plots were either sealed with a clear plastic 4-mil tarp or they were left unsealed. Plots that were treated with dazomet twice at a 5-d interval were left uncovered following the initial treatment, and then covered following the second application if called for in the treatment plan. Water was applied using a hand-operated sprayer, which the applicator used in conjunction with a hand-held timer to dispense the desired amount. Each time trial subplot was split into 22 sub-subplots $(2 \times 4 \mathrm{ft})$ and the combinations of two soil preparation levels and 11 treatment regimens were randomly assigned to sub-subplots within each subplot. Surrounding the individual sub-subplots was a border measuring $2 \mathrm{ft}$ on each side for tarping; previous studies have shown this border size to be adequate in suppressing the lateral movement of methyl isothiocyanate gas (Jeffries et al., 2017). The 4-mil clear plastic tarps were removed 7 $\mathrm{d}$ after treatment. Annual bluegrass counts were made by randomly placing a $\mathrm{l} \times \mathrm{l}-\mathrm{ft}$ grid within each individual plot and counting the number of annual bluegrass seedlings within the grid. The count was made $56 \mathrm{~d}$ following initial dazomet application.

This experimental procedure was performed twice during Summer 2015. Trial I was initiated on 24 June,

Table 1. Treatment list categorized into individual parameters for efficacy of dazomet for the control of annual bluegrass seed study in 2015 at East Lansing, MI. The 11 treatment parameters encompass dazomet application rate, incorporation method, and the technique used to seal the soil surface.

\begin{tabular}{|c|c|c|c|c|c|}
\hline $\begin{array}{l}\text { Treatment } \\
\text { no. }\end{array}$ & $\begin{array}{c}\text { Treatment } \\
\text { code }^{\mathrm{z}}\end{array}$ & $\begin{array}{c}\text { Dazomet } \\
\text { application } \\
\text { rate } \\
(\text { lb } / \text { acre })^{y}\end{array}$ & $\begin{array}{c}\text { Incorporation } \\
\text { method }^{\mathrm{x}}\end{array}$ & $\begin{array}{l}\text { Irrigation } \\
\text { schedule }^{\mathrm{x}}\end{array}$ & $\begin{array}{c}\text { Tarp } \\
\text { application }^{\mathrm{w}}\end{array}$ \\
\hline 1 & $421-\mathrm{P}$ & 421 & Physical & $\mathrm{N}$ & No \\
\hline 2 & $421-P+T$ & 421 & Physical & $\mathrm{N}$ & Yes \\
\hline 3 & $525-\mathrm{P}$ & 525 & Physical & $\mathrm{N}$ & No \\
\hline 4 & $525-\mathrm{P}+\mathrm{T}$ & 525 & Physical & $\mathrm{N}$ & Yes \\
\hline 5 & 262-MW & 262 & Water & 1 & No \\
\hline 6 & 262-SW+T & 262 & Water & 2 & Yes \\
\hline 7 & $262 \times 2-M W$ & $262 \times 2$ & Water & 1 & No \\
\hline 8 & $262 \times 2-S W+T$ & $262 \times 2$ & Water & 2 & Yes \\
\hline 9 & 525-MW & 525 & Water & 1 & No \\
\hline 10 & 525-SW+T & 525 & Water & 2 & Yes \\
\hline 11 & Control & Control & - & - & - \\
\hline
\end{tabular}

${ }^{\mathrm{z}} \mathrm{MW}=$ water applied multiple times following schedule $1 ; \mathrm{SW}=$ water applied once following schedule 2.

${ }^{\mathrm{y}} 1 \mathrm{lb} / \mathrm{acre}=1.1209 \mathrm{~kg} \cdot \mathrm{ha}^{-1}$

${ }^{\mathrm{x}}$ Physical $=$ manually incorporated into the soil using a rotary tiller; Water $=$ incorporated with $\mathrm{l}$ inch of water; $\mathrm{N}=$ no irrigation; $1=1$ inch of irrigation immediately after application, $0.5,0.25,0.125$ inch each day after application, respectively; $2=1$ inch of irrigation immediately after application $(1$ inch $=2.54 \mathrm{~cm})$.

"Yes $=$ covered with 4 -mil $(0.1 \mathrm{~mm})$ plastic tarp following incorporation. 
and trial II commenced on 15 Aug. The collected data were organized into a digital workbook (Excel; Microsoft Corp., Redmond, WA) and then SAS software (version 9.4; SAS Institute, Cary, NC) was used to compare means. Researchers used PROC MIXED to analyze and compare mean values from the collected data. Mean values were separated according to Fisher's protected least significant difference (LSD) test at $P<0.05$ level.

\section{Results and discussion}

Following a complete statistical analysis, researchers were able to conclude that there were no significant differences between the two separate trials, and therefore results could be pooled (Table 2). From there, a significant interaction occurred between soil type and soil preparation as well as between soil type and treatment. A three-way interaction also occurred between trial, treatment, and soil preparation.

The first interaction, soil type $\times$ soil preparation, saw reduced annual bluegrass germination in plots that had the top 1.5 inches of material removed (Table 3), regardless of plot soil types. All treatments that were applied in sand topdressed soils showed lower numbers of annual bluegrass as compared with native soils, regardless of the method of soil preparation (Table 3 ).

The second interaction, soil type $x$ treatment, saw substantial control of annual bluegrass in all treatments that were tarped, regardless of the soil type (Table 4). The double application treatment did see an increase in annual bluegrass numbers, even when tarped following the second application. Treatments incorporated with water and then tarped, showed better control in sand topdressed soils compared with native soils. Notably, treatment 7 which was left uncovered after dazomet was applied twice (262 lb/acre) at a 5-d interval and treatment 9 which was left uncovered following application of the highest rate of dazomet (525 lb/acre) suppressed germination of annual bluegrass equally well when compared with the control.

The three-way interaction between trial, treatment, and soil preparation again saw acceptable control in tarped plots (Table 5 ). This was true for all but the double application

Table 2. Analysis of variance results for annual bluegrass germination following application of dazomet $56 \mathrm{~d}$ after treatment in 2015 at East Lansing, MI.

\begin{tabular}{lc}
\hline Source of variation & $P>\mathbf{F}$ \\
\hline Soil type & 0.1171 \\
Trial & 0.8417 \\
Soil $\times$ trial & 0.6423 \\
Soil preparation & $<0.0001^{*}$ \\
Soil type $\times$ soil preparation & $0.0252^{*}$ \\
Trial $\times$ soil preparation & 0.2286 \\
Soil type $\times$ trial $\times$ soil preparation & 0.3046 \\
Treatment & $<0.0001^{*}$ \\
Soil type $\times$ treatment & $0.0002^{*}$ \\
Trial $\times$ treatment & $<0.0001^{*}$ \\
Soil type $\times$ trial $\times$ treatment & 0.3404 \\
Soil preparation $\times$ treatment & $<0.0001^{*}$ \\
Soil type $\times$ soil preparation $\times$ treatment & 0.2092 \\
Trial $\times$ soil preparation $\times$ treatment & $<0.0001^{*}$ \\
Soil type $\times$ trial $\times$ soil preparation $\times$ treatment & 0.1786 \\
\hline
\end{tabular}

*Significant at the $0.05 P$ level.

Table 3. Effects of soil type $\times$ soil preparation on annual bluegrass germination $56 \mathrm{~d}$ after treatment in 2015 at East Lansing, MI.

\begin{tabular}{|c|c|c|}
\hline \multirow[b]{2}{*}{ Soil type $^{\mathrm{z}}$} & \multicolumn{2}{|c|}{ Soil preparation } \\
\hline & $\begin{array}{c}\text { Sod removed avg } \\
\text { plant count }\left(\text { no. } / \mathrm{ft}^{2}\right)^{\mathrm{y}}\end{array}$ & $\begin{array}{c}\text { Glyphosate avg plant } \\
\text { count }\left(\text { no. } / \mathrm{ft}^{2}\right)\end{array}$ \\
\hline Sand & $2.1 \mathrm{~d}^{\mathrm{x}}$ & $10.4 \mathrm{~b}$ \\
\hline Native soil & $6.2 \mathrm{c}$ & $20.7 \mathrm{a}$ \\
\hline \multicolumn{3}{|c|}{$\begin{array}{l}{ }^{2} \text { Sand }=\text { sand-capped soil topdressed biweekly at a rate of } 0.14 \mathrm{yard}^{3} / 1000 \mathrm{ft}^{2}\left(11.521 \mathrm{~m}^{3} \cdot \mathrm{ha}^{-1}\right) \text { every growing } \\
\text { season since } 2011 \text {; accumulating a total of } 1.5 \text { inches }(3.81 \mathrm{~cm} \text { ) of sand; Native soil }=\text { native Capac loam (fine- } \\
\text { loamy, mixed, mesic Aquic Glossudalfs) with a bulk density of } 1.5 \mathrm{~g} \cdot \mathrm{cm}^{-3} \text {, a pH of } 6.6 \text { and } 2.5 \% \text { (by weight) organic } \\
\text { matter on average. } \\
{ }^{y} 1 \text { plant } / \mathrm{ft}^{2}=10.7639 \text { plants } / \mathrm{m}^{2} \text {. } \\
{ }^{2} \text { Mean values separated according to Fisher's protected LSD at } P<0.05 \text {. }\end{array}$} \\
\hline
\end{tabular}

Table 4. Effects of soil type $\times$ dazomet treatment on annual bluegrass germination $56 \mathrm{~d}$ after treatment in 2015 at East Lansing, MI.

\begin{tabular}{|c|c|c|}
\hline \multirow[b]{3}{*}{ Treatment code ${ }^{\mathrm{z}}$} & \multicolumn{2}{|c|}{ Soil type ${ }^{y}$} \\
\hline & Sand & Native soil \\
\hline & \multicolumn{2}{|c|}{ Avg plant count $\left(\right.$ no. $\left./ \mathrm{ft}^{2}\right)$} \\
\hline 1) $421-\mathrm{P}$ & $4.6 \mathrm{efg}^{\mathrm{x}}$ & 8.5 defg \\
\hline 2) $42 \mathrm{l}-\mathrm{P}+\mathrm{T}$ & $0 \mathrm{~g}$ & $0.2 \mathrm{~g}$ \\
\hline 3) $525-\mathrm{P}$ & $2 \mathrm{fg}$ & $8.3 \mathrm{defg}$ \\
\hline 4) $525-\mathrm{P}+\mathrm{T}$ & $0 \mathrm{~g}$ & $0.2 \mathrm{~g}$ \\
\hline 5) $262-\mathrm{MW}$ & 10.7 def & $25.1 \mathrm{c}$ \\
\hline 6) $262-\mathrm{SW}+\mathrm{T}$ & $0.3 \mathrm{~g}$ & $0.5 \mathrm{~g}$ \\
\hline 7) $262 \times 2-\mathrm{MW}$ & $3.8 \mathrm{fg}$ & $14.1 \mathrm{~d}$ \\
\hline 8) $262 \times 2-S W+T$ & $3.2 \mathrm{fg}$ & 8.2 defg \\
\hline 9) $525-\mathrm{MW}$ & $3.2 \mathrm{fg}$ & $13 \mathrm{de}$ \\
\hline 10) $525-\mathrm{SW}+\mathrm{T}$ & $0.1 \mathrm{~g}$ & $0 \mathrm{~g}$ \\
\hline 11) Control & $41.2 \mathrm{~b}$ & $69.8 \mathrm{a}$ \\
\hline
\end{tabular}

${ }^{\mathrm{z}}$ Description of dazomet treatment factor, begins with rate, followed by incorporation, and finally an indication of whether an impermeable tarp was used to seal surface. See Table 1 for full treatment description.

${ }^{\mathrm{y}}$ Sand $=$ sand-capped soil topdressed biweekly at a rate of $0.14 \mathrm{yard}^{3} / 1000 \mathrm{ft}^{2}\left(11.521 \mathrm{~m}^{3} \cdot \mathrm{ha}^{-1}\right)$ every growing season since 2011 ; accumulating a total of 1.5 inches $(3.81 \mathrm{~cm})$ of sand; Native = native Capac loam (fine-loamy, mixed, mesic Aquic Glossudalfs) with a bulk density of $1.5 \mathrm{~g} \cdot \mathrm{cm}^{-3}$, a pH of 6.6 and $2.5 \%$ (by weight) organic matter on average $\left(1\right.$ plant $/ \mathrm{ft}^{2}=10.7639$ plants $\left./ \mathrm{m}^{2}\right)$.

${ }^{\mathrm{x}}$ Mean values separated according to Fisher's protected LSD at $P<0.05$.

treatment, which was tarped after the second dazomet application. Annual bluegrass numbers were significantly greater here than in other tarped plots, mainly seen in glyphosatetreated plots, especially in the second 
Table 5. Effects of trial $\times$ soil preparation $\times$ dazomet treatment on annual bluegrass germination $56 \mathrm{~d}$ after treatment in 2015 at East Lansing, MI.

\begin{tabular}{|c|c|c|c|c|}
\hline \multirow[b]{4}{*}{ Treatment code ${ }^{\mathrm{z}}$} & \multicolumn{4}{|c|}{ Trial $^{y}$} \\
\hline & \multicolumn{2}{|c|}{ First } & \multicolumn{2}{|c|}{ Second } \\
\hline & Sod removed & Glyphosate & Sod removed & Glyphosate \\
\hline & \multicolumn{4}{|c|}{ Avg plant count $\left(\right.$ no. $\left./ \mathrm{ft}^{2}\right)$} \\
\hline 1) $421-\mathrm{P}$ & $0.8 \mathrm{j}^{\mathrm{x}}$ & $2.2 \mathrm{~d}$ & 3.2 ghij & 19 cdef \\
\hline 2) $421-P+T$ & $0 \mathrm{j}$ & $0 \mathrm{j}$ & $0 \mathrm{j}$ & $0.3 \mathrm{j}$ \\
\hline 3) $525-\mathrm{P}$ & 2 hij & 2.5 hij & $1.3 \mathrm{j}$ & 14.7 defgh \\
\hline 4) $525-\mathrm{P}+\mathrm{T}$ & $0.2 \mathrm{j}$ & $0 \mathrm{j}$ & $0 \mathrm{j}$ & $0.2 \mathrm{j}$ \\
\hline 5) $262-\mathrm{MW}$ & 5 ghij & 24.3 cde & 14.2 defghi & $28 \mathrm{c}$ \\
\hline 6) $262-\mathrm{SW}+\mathrm{T}$ & $0 \mathrm{j}$ & $0 \mathrm{j}$ & $1 \mathrm{j}$ & $0.5 \mathrm{j}$ \\
\hline 7) $262 \times 2-M W$ & $0.8 \mathrm{j}$ & 4.3 ghij & 4.5 ghij & $26.2 \mathrm{~cd}$ \\
\hline 8) $262 \times 2-S W+T$ & $0.7 \mathrm{j}$ & 4.7 ghij & $1.5 \mathrm{ij}$ & 15.8 cdefg \\
\hline 9) 525-MW & $1.8 \mathrm{ij}$ & 12.2 efghij & 9.7 fghij & 8.7 fghij \\
\hline 10) $525-\mathrm{SW}+\mathrm{T}$ & $0 \mathrm{j}$ & $0 \mathrm{j}$ & $0.2 \mathrm{j}$ & $0 \mathrm{j}$ \\
\hline 11) Control & $23.5 \mathrm{cde}$ & $127.3 \mathrm{a}$ & $21 \mathrm{cdef}$ & $50.1 \mathrm{~b}$ \\
\hline
\end{tabular}

${ }^{\mathrm{z}}$ Description of dazomet treatment factor, begins with rate, followed by incorporation, and finally an indication of whether an impermeable tarp was used to seal surface. See Table 1 for full treatment description.

${ }^{\mathrm{y}}$ First $=$ initiated on 24 June 2015; Second $=$ initiated on 15 Aug. 2015; Sod removed $=$ experimental plots were prepared by removing the upper layer of tissue and soil; Glyphosate $=$ experimental plots were prepared by applying glyphosate and then aggressive cultivation $\left(1\right.$ plant $/ \mathrm{ft}^{2}=10.7639$ plants $/ \mathrm{m}^{2}$ ).

${ }^{x}$ Mean values separated according to Fisher's protected LSD at $P<0.05$.

trial. Overall, plots with the top 1.5 inches of material removed saw greater annual bluegrass control than plots that were treated with glyphosate, regardless of trial or treatment. Finally, the second trial did have some reduced control, namely in the $\mathrm{P}$ incorporated, glyphosate-treated plots as well as in the glyphosate-treated, double application tarped plots.

It can be speculated that by removing 1.5 inches of the existing material in the sod cut plots, a large portion of the viable seed bank layer was also removed, leading to the reduced amount of annual bluegrass. Previous research had shown that incorporating dazomet into the top 0.5 inch of the soil profile would control the majority of the annual bluegrass seed bank (Branham et al., 2004). Additionally, in the sand topdressed plots, it is assumed that the added sand suppressed part of the previously established seed bank, allowing for greater control of annual bluegrass. Finally, trial two may have seen a slight decrease in control in a few treatments because of increased soil temperatures at the time of study, creating a more suitable environment for annual bluegrass germination. Average soil temperatures in June 2015 were $\approx 70{ }^{\circ} \mathrm{F}$ and in August, soil temperatures increased to nearly $76^{\circ} \mathrm{F}$.

To summarize these results, dazomet showed increased control of annual bluegrass germination in both sand topdressed plots and plots that were a native Capac loam soil when sod was removed before application when compared with glyphosate-treated plots. Furthermore, the use of an impermeable tarp increased efficacy of dazomet in controlling annual bluegrass germination. Finally, the removal of 1.5 inches of material from the soil surface before dazomet application, compared with applying glyphosate and cultivating before application, led to greater germination inhibition. Future research should investigate dazomet treatments in combination with the removal of the top few inches of soil and plant material, specifically through a soil scarification technique, as well as the effectiveness of multiple applications of dazomet at specific intervals to eliminate the need for an impermeable cover.

\section{Literature cited}

Askew, S.D., J.B. Beam, and W.L. Barker. 2004. Dazomet for renovating turfgrass infested with nimblewill. Proc. Northeastern Weed Sci. Soc. 58:100.
Branham, B.E., G.A. Hardebeck, J.W Meyer, and Z.J. Reicher. 2004. Turfgrass renovation using dazomet to control the annual bluegrass L. soil seed bank. HortScience 39:1763-1767.

Brecke, B.J., J.B. Unruh, and D.O. Stephenson. IV. 2005. Dazomet blended with rootzone mix for fumigation. Intl. Turfgrass Soc. Res. J. 10(part 2):1176-1178.

Calhoun, R.N. and B.E. Branham. 1995. Controlling annual bluegrass seeds in topsoil with a granular soil sterilant. Proc. 65th Annu. Michigan Turfgrass Conf. 24:63-64.

Hardebeck, G., Z. Reicher, and B. Branham. 2001. Optimizing the use of Basamid for annual bluegrass control in fairway renovation-2001.2001 Annual report, Purdue Univ. Turfgrass Sci. Prog., West Lafayette, IN. p. 66-70.

Jeffries, M.D., T.W. Gannon, W.C. Reynolds, F.H. Yelverton, and C.A. Silcox. 2017. Herbicide applications and incorporation methods affect dazomet efficacy on bermudagrass. HortTechnology 27:24-29.

McClellan, T. 2009. Will the real alternative to methyl bromide please stand up? Fumigation facts you should know if your golf facility is considering putting green renovation. USGA Green Sect. Rec. $47(2): 14-18$.

Park, B.S. and P.J. Landschoot. 2001. Effects of plastic covering and basamid rate on $P$. annua seedling emergence in fairway turf. 2001 Annual research report, Pennsylvania State Univ., University Park, PA. p. 11-15.

Park, B.S. and P.J. Landschoot. 2003. Effect of dazomet on annual bluegrass emergence and creeping bentgrass establishment in turf maintained as a golf course fairway. Crop Sci. 43(4):1387-1394.

Ristaino, J.B. and W. Thomas. 1997. Agriculture, methyl bromide, and the ozone hole: Can we fill the gaps? Plant Dis. 81(9):964-977.

Skorulski, J., J. Henderson, and N.A. Miller. 2010. Topdressing fairways: More is better. USGA Green Sect. Rec. $48(2): 15-17$.

Unruh, B.J., B.J. Brecke, J.A. Dusky, and J.S. Godbehere. 2002. Fumigant alternatives for methyl bromide prior to turfgrass establishment. Weed Technol. 16(2):379387. 